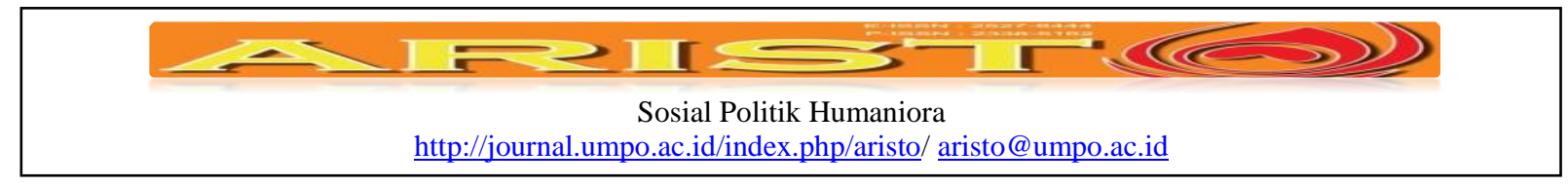

\title{
Peran Manajerial dan Teknisi Humas Lembaga Pemerintah dan Swasta
}

\author{
Rachmat Kriyantono \\ Program Ilmu Komunikasi, Fakulas Ilmu Sosial dain Ilmu Politik \\ Universitas Brawijaya Malang \\ Rachmat_kr@ub.ac.id
}

\begin{abstract}
The research aims to describe the implementation level of managerial and technician roles of public relations practitioners from government and private institutions in Indonesia. The hypothesis is public relations from private institutions often more apply the managerial roles while the practitioners from government public relations tend to apply technical communication than managerial roles of communication. The researcher uses positivistic paradigm by applying survey method with questioners which are filled by 105 respondents. The instrument are from FiveFactor Dimension Model that specifically measures the level of managerial and technician roles of communication. The research finds that there is no significant differentiation between public relations practitioners from government and private institutions regarding the dimensions of managerial and technician roles. Both practitioners frequently apply technician roles rather than managerial roles, however, the government public relations more frequently conduct managerial roles than practitioners from private institutions. The research contributes to the development of public relations study and practice in Indonesia by testing the managerial and technical roles conducting by public relations practitioners through using Five-factor Model.
\end{abstract}

\section{Keyword: Communication, Five-factor Moderl, Managerial, Public Relations, Technician Role}

\begin{abstract}
Abstrak
Penelitian ini bertujuan mendeskripsikan level penerapan peran manajerial dan teknisi komunikasi pada praktisi Hubungan Masyarakat (Humas) lembaga pemerintah dan swasta di Indonesia. Hipotesis penelitian yang diuji adalah Humas swasta lebih sering menjalankan peran manajerial daripada peran teknis komunikasi sedangkan Humas pemerintah lebih sering menjalankan peran teknis komunikasi daripada peran manajerial komunikasi. Peneliti menggunakan paradigm positivistic dengan metode survey dengan kuesioner yang diisi 105 responden. Instrumen yang digunakan berasal dari Five-Factor Dimension Model yang khusus mengukur level peran manajerial dan teknisi komunikasi dalam organisasi. Penelitian ini menemukan bahwa tidak ada perbedaan signifikan antara praktik Humas pemerintah dan swasta terkait dengan dimensi peran manajerial dan teknisi komunikasi. Kedua jenis Humas sama-sama lebih sering menerapkan peran teknisi komunikasi daripada peran manajerial komunikasi, namun Humas pemerintah lebih sering melakukan peran manajerial daripada Humas swasta.Penelitian ini berkontribusi bagi pengembangan kajian dan praktik kehumasan di Indonesia, yakni pengujian peran manajerial dan teknisi yang dilakukan praktisi kehumasandengan menggunakan Five-Factor Dimension Model.

Keyword: Five-factor Dimension Model, Hubungan Masyarakat, Komunikasi, Manajerial, Technician Role
\end{abstract}

\begin{tabular}{|ll|}
\hline Submite & $:$ 10Agustus 2017 \\
Review & $:$ 25Oktober 2017 \\
Accepted & $:$ 01 Januari 2018 \\
Surel Corespondensi & $:$ winda86@ gmail.com \\
\hline
\end{tabular}

Rachmat Kriyantono, Peran Manajerial dan Teknisi Humas Lembaga Pemerintah dan Swasta/01/ Vol. 6. No.1. Tahun 2018 


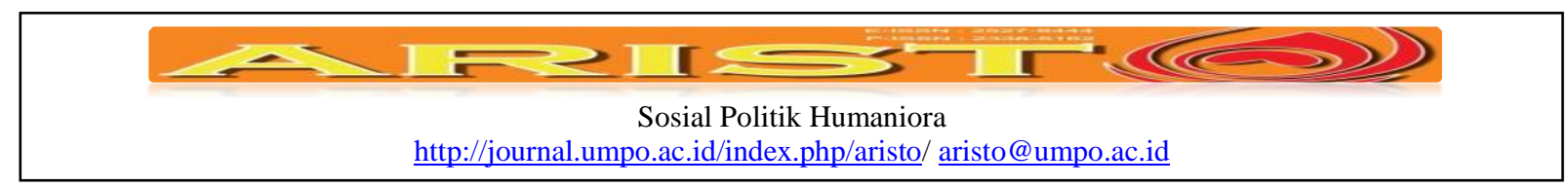

\section{Pendahuluan}

Hubungan Masyarakat (Humas/Public Relations) merupakan aktivitas komunikasi, karena menurut Grunig dan Hunt (1984, h. 6). "Humas adalah manajemen komunikasi antara organisasi dengan publiknya". Menurut Culbertson, dkk (1993), "Humas adalah management by communication". Komunikasi menjadi bagian dari Humas karena menurut Wilcox, Ault, dan Agee (2006) komunikasi adalah proses dan sarana yang digunakan untuk mencapai sasaran Humas misalnya melalui sambutan-sambutan, brosur, gambar tempel dan sejenisnya. Jadi dapat disimpulkan bahwa "komunikasi sebagai alat utama Humas memainkan peran sentral dalam proses saling keberhubungan antara organisasi, Humas, dan publiknya" (Kriyantono, 2014a, h.83).

"Peran diartikan sebagai aktifitas sehari-sehari yang dilakukan praktisi Humas sesuai dengan kedudukannya" (Kriyantono, 2014a, h. 83). Beberapa literatur, seperti Cutlip, Center \& Broom (2011); Kriyantono (2014a); Lattimore, D., Baskin, O., Heiman, S., \& Toth, E(2010) mendeskripsikan peran Humas terbagi menjadi dua yaitu peran manajerial dan teknisi (craft). Peran manajerial, yakni 1) Expert Prescriber merupakan seorang ahli yang mampu mendifinisikan masalah, mengusulkan berbagai alternatif pemecah masalah, dan melaksanakan upaya pemecah masalahnya, 2) Communication facilitator merupakan seseorang yang menjadi mediator dan fasilitator yang menyediakan saluran untuk berkomunikasi secara dua arah yang timbal balik antara organisasi dan publiknya dan praktisi Humas bertindak sebagai penghubung antara organisasi dengan publiknya, 3) Problem Solving Facilitator merupakan seseorang yang mampu bertindak sebagai partner, mitra atau teman bagi manajemen senior dalam upaya mengatasi berbagai persoalan yang menimpa organisasi, 4) Communication technician merupakan hal-hal yang menyangkut pekerjaan teknis seperti menulis press release, membuat news letter, fotografi, membuat produksi audiovisual, menggelar event, dan mengembangkan isi website.

Ketiga peran (Expert Prescriber, Communication facilitator, Problem Solving Facilitator) merupakan peran manajerial karena pelakunya harus memiliki kemampuan berpikir strategis (strategic thinking)dalam melakukannya dan bukan semata berdasarkan keterampilan teknis komunikasi saja. Selanjutnya, communication technicianmasuk ke dalam kategori teknisi karena berbagai aktivitasnya hanya berdasarkan kemampuan teknis komunikasi, seperti membuat brosur, membuat press release, membuat kalender, membuat majalah, dan protokoler. Praktisi 


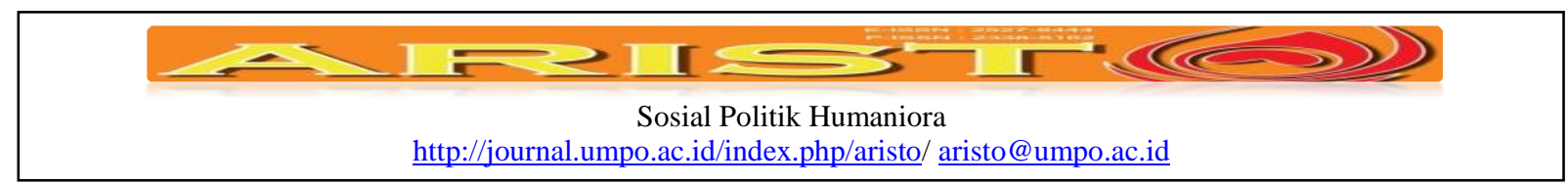

yang melakukan kegiatan teknis komunikasi ini juga tidak dilibatkan dalam pengambilan keputusan atau kebijakan di organisasinya(Cutlip, dkk, 2011; Kriyantono,2014a; Lattimore, dkk, 2010).

Beberapa penelitian peran Humas juga berfokus pada keterampilan dan kompetensi yang dibutuhkan oleh praktisi untuk berpindah dari jajaran Humas teknisi untuk posisi manajemen. Setelah melakukan penelitian di AS, Inggris, dan Kanada, J. E. Grunig, L. Grunig, dan Dozier (2002) menemukan bahwa Humas yang ekselen adalah yang banyak melakukan peran manajerial daripada peran teknisi. Peran-peran Humas di atas, menurut hasil riset Jayanti (2011) dimungkinkan dapat dilakukan oleh semua praktisi Humas. Kriyantono (2017) meneliti keekselenan aktivitas praktisi Humas lembaga pemerintah dan swasta di Indonesia dengan menggunakan ukuran normatif kehumasan yang ekselen dari J. E. Grunig, dkk (2002). Penelitian ini menemukan bahwa Humas lembaga swasta lebih ekselen daripada lembaga pemerintah. Faktor yang membuat Humas swasta lebih ekselen, menurut Kriyantono (2017), antara lain karena komunikasi dua arah yang simetris dari Humas lembaga swasta lebih tinggi dan Humas swasta lebih dilibatkan dalam fungsi-fungsi manajerial daripada Humas lembaga pemerintah.

Selain ukuran normatif yang dikenalkan J.E. Grunig, dkk (2002), terdapat ukuran lain yang dapat digunakan mengevaluasi level penerapan peran manajerial dan teknisi yang dilakukan praktisi Humas. Ukuran ini adalah Five-Factor Dimension Model yang dikembangkan oleh Moss, Newman \& De Santo (baca Moss, Newman \& De Santo, 2005; De Santo, Moss,\& Newman, 2007). Jika model J.E. Grunig, dkk (2002) bertujuan mengukur level keekselenan aktivitas kehumasan secara keseluruhan, yakni meliputi struktur organisasi kehumasan, peran, arah komunikasi, etika kehumasan, penggunaan basis teoritis dalam aktivitas kehumasan, dan relasi dengan fungsi-fungsi manajemen lainnya, maka Five-Factor Dimension Model ini lebih spesifik mengevaluasi level peran manajerial dan teknisisebagai indikator sejauh mana praktisi Humas berperan sebagai bagian manajemen organisasi (DeSanto, dkk, 2007). Fokus pada peran manajerial sebagai bagian manajemen ini juga diperkuat pendapat Harold Burson (dalam Wilcox \& Cameron, 2009) bahwa Humas berperan sebagai bagian manajemen yang terintegrasi secara tidak terpisah dalam struktur organisasi dan peran ini sangat penting karena berkontribusi menentukan keberhasilan organisasi mencapai visi, misi, dan tujuan bersama.

Five-Factor Dimension Model ini pernah digunakan oleh Perthawa, Kriyantono, dan Wisadirana (2015) untuk mengevaluasi level peran manajerial praktisi kehumasan anggota 


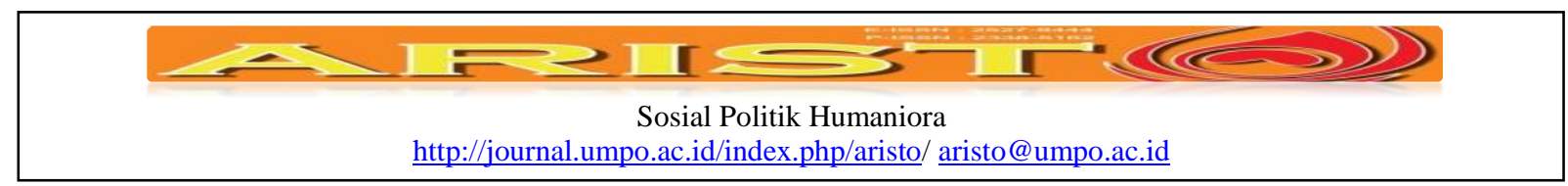

pengurus pusat perhimpunan Humas (perhumas) di Jakarta. Hasil penelitian ini adalah para praktisi mengakui telah melakukan peran manajerial dalam aktivitas kehumasan mereka.Penelitian ini penting dilakukan untuk menguji apakah hasil penelitian terdahulu, yakni Grunig, dkk (2002) masih terbukti hasilnya jika dilakukan dalam konteks aktivitas kehumasan di Indonesia dengan menggunakan Five-Factor Dimension Model? Apakah hasil penelitian Kriyantono (2017) juga masih terbukti hasilnya dengan menggunakan model pengukuran berbeda? Apakah hasil penelitian Perthawa, dkk (2015) terhadap praktisi di Jakarta dengan menggunakan Five-Factor Dimension Model akan menghasilkan hasil yang sama jika objek penelitiannya diperluas wilayah lain?

Deskripsi tentang peran Humas ini makin penting karena Indonesia telah memasuki era reformasi politik sejak 1998 yang membuka demokratisasi dan kebebasan berbicara (Kriyantono, Ramadlan, \& Setiawan, 2015; Siriyuvasak, 2005). Demokrasi, pada akhirnya, menstimuli aktivitas komunikasi dengan publik yang memerlukan praktisi Hubungan Masyarakat (Humas/Public relations) untuk menghandle-nya (Kriyantono, 2014a; Kriyantono, dkk, 2015; Sriramesh \& Vercic, 2009). Menarik diteliti apakah praktisi Humas lebih berperan manajerial atau teknis dalam mengelola strategi komunikasi di era demokrasi ini.Penelitian ini berkontribusi bagi pengembangan kajian dan praktik kehumasan di Indonesia, yakni pengujian peran manajerial dan teknisi yang dilakukan praktisi kehumasan dengan menggunakan Five-Factor Dimension Model. Penelitian ini juga penting dilakukan karena penelitian kehumasan dalam perspektif kelokalan Indonesia masih perlu ditingkatkan (Kriyantono \& McKenna, 2017).

\section{Metode dan Kajian Pustaka}

\section{Five-factor Dimension Model}

Five-factor Dimension Model merupakan penggabungan antara dimensi teknis dan empat dimensi managerial yang berfokus pada aktivitas key policy danstrategy advisor; monitor danevaluator; troubleshooter/problemsolver; danissuesmanagementexpert serta dimesiteknis. Model ini bertujuan mengetahui level pentingnya kedudukan dan peran praktisi Humas dalam organisasi dalam hubungan antara praktisi Humas dengan manajemen puncak dan manajemen lain sehingga mereka dapat berkolaborasi secara baik. (De Santo, dkk, 2007; Moss, dkk, 2005).

Model ini menyiapkan konsep peran dan mengklarifiasi dimensi spesifik dari aktivitas kerja Humas pada ranah bisnis (De Santo, dkk, 2007; Moss dkk, 2005). Menurut Moss, dkk 


Sosial Politik Humaniora
http://journal.umpo.ac.id/index.php/aristo/ aristo@umpo.ac.id

(2011, h. 107), model ini dapat membantu meningkatkan kualitas praktisi Humas, seperti kemampuan bekerja sama dengan manajemen senior untuk menyusun nilai-nilai organisasi, prinsip-prinsip operasional, kebijakan, dan strategi-strategi organisasi, membantu meningkatkan kemampuan manajemen isu, masalah, dan identifikasi peluang-peluang, meningkatkan kemampuan membantu organisasi mengejar tujuan mencapai keuntungan bisnis, dan kemampuan memahami kompleksitas komunikasi dengan departemen lain dalam organisasi. Untuk itu, kelima dimensi dalam five-factor dimension model,yakni (i) key policydanstrategy advisor; (ii) monitor danevaluator;(iii) trouble shooter atauproblem solver; (iv) issues management expert, dan (v) communication technician, digunakan oleh peneliti sebagai indikator untuk melihat sejauh mana level manajerial para praktisiHumasdi Indonesia. Lima dimensi five-factor dimension model adalah sebagai berikut (De Santo, dkk, 2007; Moss \& De Santo, 2011; Whitaker, 2014):

1. Key policy and strategy advisor. Praktisi Humasmempunyai hubungan yang baik dengan manajemen senior dan secara aktif terlibat dalam proses pengambilan keputusan.

2. Monitor and evaluator.Elemen ini menjelaskan bahwa tingkat tanggungjawab manajerial praktisi Humas adalah untuk melakukan organizing, controlling serta monitoring kerja diinternal bagian Humas maupun eksternal di bagian-bagian lain dalam organisasi. Di internal humas, praktisi Humas bertanggungjawab untuk menetapkan target, anggaran dan pemantauan kinerja terhadap target tersebut. Mereka harus melakukan negosiasi dengan bagian lain, termasuk manajemen senior, untuk menetapkan target serta bernegosiasi tentang sumber daya dan agen komisi eksternal.

3. Issues management expert.Kemampuan praktisi Humasuntuk mendiagnosis masalah dan mengantisipasi ancaman eksternal, baik isu besar ataupun kecil, dan harus memiliki kepekaan sebagai mata dan telinga eksternal organisasi.

4. Trouble shooter/problem solver.Peran praktisi dalam merespon ancaman dari internal maupun tantangan dari eksternal, ancaman dan krisis yang melanda organisasi, dan menciptakan pemahaman kepada angggota organisasi bahwa organisasinya tangguh.

5. Communication technician.Lebih berperan dalam aspek teknis komunikasi, seperti menulis untuk media dan newsletter, meng-handle event serta bekerjasama dengan media. 


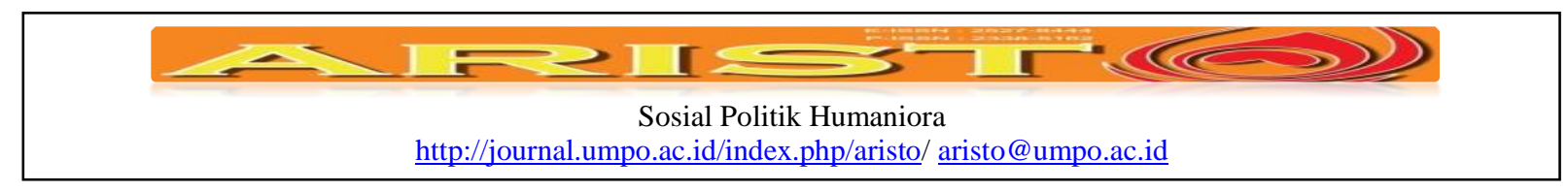

\section{Hubungan Masyarakat Lembaga Pemerintah dan Swasta di Era Demokrasi}

Demokrasi dan teknologi komunikasi membuat publik mendapatkan akses informasi lebih mudah, lebih kritis, dan bebas menulis pendapat atau membuat berita di media sosial (Kriyantono, dkk, 2015), media bebas menulis informasi tanpa takut kepada pemerintah (Siriyuvasak, 2005), dan informasi ini dikonsumsi para akademisi dan pelajar yang juga menjadi elemen penting mempromosikan demokratisasi di Indonesia (Kriyantono, dkk, 2015).

Demokrasi, pada akhirnya, menstimuli aktivitas komunikasi dengan publik yang memerlukan praktisi Hubungan Masyarakat (Humas/Public relations) untuk menghandle-nya (Kriyantono, 2014a; Sriramesh \& Vercic, 2009). Aktivitas komunikasi ini merupakan implikasi dari sifat demokrasi, yang menurut Taylor (2000), sebagai proses nation-building yang mensyaratkan jalinan relasi antara individu dan pemerintah, melalui kampanye komunikasi. Karena itu, bukan situasi yang mengherankan jika pertumbuhan praktik Humas di dunia semakin meningkat seiring berkembangnya demokratisasi dan teknologi (Sriramesh \& Vercic, 2009).

Beberapa kajian ilmiah, seperti Hardjana (2000); Kriyantono (2015); Kriyantono dan McKenna (2017); Grunig, dkk (2002), semakin membuktikan pentingnya pengelolaan komunikasi dalam penyelenggaraan pelayanan di organisasi. Organisasi yang berhasil selalu didukung oleh sistem komunikasi yang efektif dan Humas yang ekselen (Grunig, dkk, 2002). Karena itu, komunikasi adalah "lifeblood of an organization" (Bailey, 1974; Rogers, 1976, dikutip di Hardjana, 2000, h. x). Mengacu pada Broom \& Sha, 2013, organisasi pemerintah sebagai lembaga publik memiliki tantangan yang sama dengan perusahaan swasta dan organisasi non-profit, seperti tantangan menjaga reputasi.

Karena itu, organisasi perlu melakukan evaluasi secara berkala terkait pelaksanaan fungsi kehumasan ini, yang menurut MacNamara (dikutip di Tymson, Lazar, \& Lazar, 2004, h. 100), karena "akuntabilitas dan pengukuran merupakan prinsip-prinsip penting proses manajemen organisasi." Evaluasi menjadi sarana menunjukkan bagaimana efektivitas Humas terhadap tujuan lembaga, bagaimana program Humas sesuai target, dan menjamin aktivitas Humas dapat lebih baik di masa berikutnya (Harrison, 2009). Karenanya, evaluasi selalu menjadi elemen dalam model proses Humas dari beberapa literatur, seperti Marston (1979) dengan model RACE (Research, Action, Communication, Evaluation); Hendrix (2000) dengan model ROPE (Research, Objectives, Program, Evaluation); Smith (2002) mengenalkan model FoSTE (Formative Research, Strategy, Tactics, Evaluation Research). 


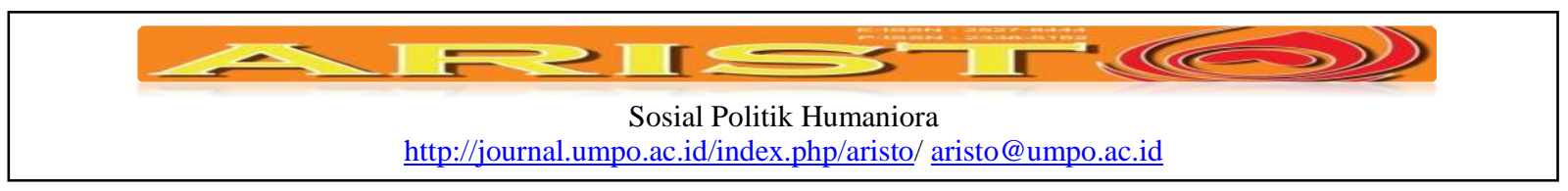

Namun demikian, dari penelitian Grunig (1989, h. 32-33; 38-39); Grunig dan White (1992, h.43-44), diketahui bahwa praktik Humas juga dipengaruhi budaya organisasi. Secara umum, Grunig (1989, h. 32-33; 38-39); Grunig dan White (1992, h.43-44) merumuskan budaya organisasi tertutup dan terbuka. Budaya tertutup lebih berorientasi internal, yaitu hanya memandang realitas dari kaca mata organisasi dan tidak memandang realitas dari kaca mata publik; Sistem tertutup, yaitu informasi tersebar dari organisasi dan tidak membuka diri pada informasi dari luar organisasi; Menganggap efisiensi dan kontrol atas segala biaya lebih penting daripada inovasi; Bersifat elitisme, yaitu pengambilan keputusan ditentukan hanya oleh pimpinan organisasi; Mempertahankan tradisi karena tradisi dianggap membantu organisasi mempertahankan stabilitas dan budaya yang sudah ada; Bersifat kewenangan terpusat, yakni hanya dimiliki manajer puncak dan tidak memberi otonomi kepada karyawan. Pada sisi lain, budaya terbuka bercirikan interdependensi, artinya organisasi merasa menjadi bagian tidak terpisah dengan lingkungannya; Sistem terbuka, yaitu organisasi bersedia bertukar informasi dan menjalin relasi dengan lingkungannya; Bergerak menuju ekuilibrium, yakni secara konstan bergerak menyesuaikan perubahan lingkungan; menghargai kesederajatan atau kesetaraan yang tinggi, yaitu anggota organisasi (pimpinan dan karyawan) berkesempatan yang sama dalam berkarya dan mendapat jenjang promosi yang jelas; Memberikan kebebasan untuk kepada anggota organisasi untuk kreatif dan inovatif dalam bekerja; Lebih mengedepankan inovasi daripada fokus pada tradisi dan kebiasaan; Desentralisasi manajemen, yaitu cenderung berbagi kewenangan. Cenderung pada koordinasi daripada mendikte.

Terkait hal itu, organisasi dinilai pemerintah memiliki perbedaan budaya dengan swasta, yakni organisasi pemerintah lebih bersifat tertutup (Ikhsan, 2015). Karenanya, Humas pemerintah masih kurang dalam penerapan komunikasi dua arah yang simetris dibanding Humas swasta (Kriyantono, 2017).

Berdasarkan literatur review di atas, peneliti merumuskan hipotesis penelitian sebagai berikut: "Humas swasta lebih sering menjalankan peran manajerial daripada peran teknis komunikasi sedangkan Humas pemerintah lebih sering menjalankan peran teknis komunikasi daripada peran manajerial komunikasi”.

Peneliti menggunakan paradigm positivistik untuk mendeskripsikan praktik Humas di Indonesia, yakni meyakini bahwa realitas hakikatnya konkrit, dapat dikategorikan, tidak berubah, dapat diukur, dan diverifikasi sehingga tipe deskriptif kuantitatif yang dipilih pun berusaha 


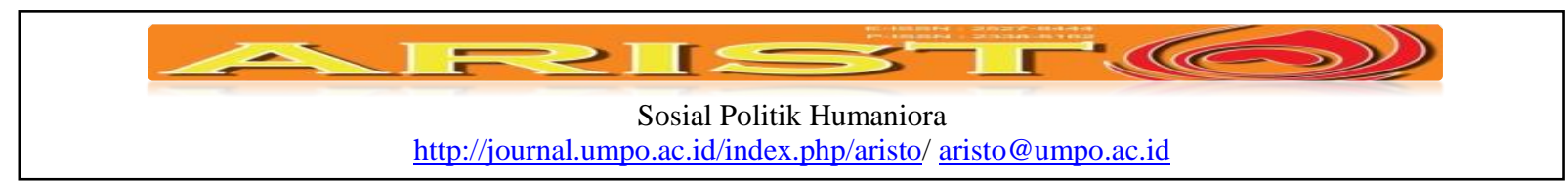

menggambarkan suatu realitas sosial yang hasilnya dapat digeneralisasikan dan menuntut penelitian bersifat objektif dan memisahkan diri dari data (Kriyantono, 2014b; Neuman, 2006; Wimmer \& Dominick, 2011). Karena bersifat deskriptif, maka penelitian ini hanya menggunakan satu variabel yang tidak menjelaskan sebab-akibat dan alasan mengapa hal tersebut bisa terjadi (Kriyantono, 2014b).

Populasi penelitian ini adalah para praktisi kehumasan di Indonesia, tetapi, karena keterbatasan akses mendapatkan responden yang memang berjumlah sangat banyak, maka penelitian ini menggunakan teknik sampling convenience, yaitu sampel yang didapatkan menurut kemudahan data yang dimiliki oleh populasi (Kriyantono, 2014b; Neuman, 2006; Wimmer \& Dominick, 2011). Responden penelitian ini adalah anggota Perhumas Indonesia, yang memiliki bagian Humas, artinya Humas dilakukan secara metode bukan hanya secara teknik komunikasi,yakni ada bagian Humas terstruktur (Kriyantono, 2014c). Peneliti telah menghubungi sekretariat Perhumas Indonesia untuk membantu penyebaran kuisioner. Dilakukan juga penyebaran kuisioner melalui email praktisi dan mendatangi langsung praktisi di tempat kerja. Dari hasil pengumpulan responden dalam waktu sekitar 4 bulan, terdapat 105 responden yang bersedia menjadi responden dengan mengisi dan mengembalikan kuesioner. Dari jumlah itu, 48 praktisi Humas organisasi swasta dan 57 Humas pemerintah.

Instrumen penelitian dalam kuesioner disusun berdasarkan Five-Factor Dimension Model yang telah diadopsi oleh beberapa penelitian terdahulu, seperti De Santo, dkk (2007); Moss \& De Santo (2011); Perthawa, dkk (2015), dan Whitaker (2014), yakni:

Tabel 1. Instrumen Kuesioner

\begin{tabular}{|c|c|c|c|}
\hline Variabel & Indikator & Deskripsi & Pernyataan dalam kuesioner \\
\hline $\begin{array}{l}\text { Five-factor } \\
\text { dimension } \\
\text { model }\end{array}$ & $\begin{array}{lr}\text { Key } & \text { Policy } \\
\text { and strategy } \\
\text { advisor }\end{array}$ & $\begin{array}{l}\text { Praktisi } r \text { Humas } \\
\text { memiliki hubungan } \\
\text { yang kuat dengan } \\
\text { manajemen senior } \\
\text { dalam organisasi } \\
\text { mereka dan memiliki } \\
\text { peran aktif dalam } \\
\text { proses pembuatan } \\
\text { kebijakan. }\end{array}$ & $\begin{array}{l}\text { 1. Saya memberikan masukan kepada pimpinan } \\
\text { secara rutin tentang isu komunikasi/bisnis dan } \\
\text { segala bentuk tantangannya. } \\
\text { 2. Saya berkontribusi secara rutin pada pembuatan } \\
\text { kebijakan perusahaan/instansi. } \\
\text { 3. Saya memberikan masukan kepada pimpinan } \\
\text { tentang cara menyampaikan sebuah kebijakan } \\
\text { dengan baik. } \\
\text { 4. Saya memberikan saran kepada pimpinan } \\
\text { tentang strategi pengambilan keputusan yang } \\
\text { nantinya akan dilihat oleh media. } \\
\text { 5. Saya memberikan masukan kepada pimpinan } \\
\text { untuk tiap isu penting yang berkaitan dengan } \\
\text { stakeholder. } \\
\text { 6. Saya bekerjasama dengan manajemen dalam }\end{array}$ \\
\hline
\end{tabular}




\begin{tabular}{|c|c|c|}
\hline \multicolumn{3}{|c|}{$\begin{array}{l}\text { Sosial Politik Humaniora } \\
\text { http://journal.umpo.ac.id/index.php/aristo/ aristo@umpo.ac.id }\end{array}$} \\
\hline & & $\begin{array}{l}\text { merumuskan strategi Humas. } \\
\text { 7. Saya terlibat langsung dalam keputusan } \\
\text { perusahaan ditingkat manajemen } \\
\text { 8. Saya bertanggungjawab dalam penerapan } \\
\text { strategi komunikasi perusahaan/instansi. } \\
\text { 9. Saya bekerjasama dengan pimpinan untuk } \\
\text { memastikan pelaksaan dari keputusan strategi } \\
\text { Humas saya telah dipahami. } \\
\text { 10. Sebuah elemen penting dalam perkerjaan saya } \\
\text { adalah melakukan perencanaan strategi Humas } \\
\text { untuk stakeholder internal maupun eksternal. }\end{array}$ \\
\hline $\begin{array}{l}\text { Monitor and } \\
\text { evaluator }\end{array}$ & $\begin{array}{ll}\text { Praktisi } & \text { Humas } \\
\text { memiliki } & \\
\text { tanggungjawab } & \\
\text { manajerial } & \text { untuk } \\
\text { melakukan } & \\
\text { organizing, } & \\
\text { controlling, } & \text { and } \\
\text { monitoring. } & \end{array}$ & $\begin{array}{l}\text { 11. Saya bekerjasama dengan pimpinan dalam } \\
\text { menentukan target yang sesuai dengan fungsi } \\
\text { Humas. } \\
\text { 12. Saya bertanggungjawab untuk menetapkan } \\
\text { target fungsi Humas. } \\
\text { 13. Saya harus memastikan bahwa fungsi } \\
\text { komunikasi Humas terlaksana sesuai dengan } \\
\text { ketentuan dan anggaran yang telah ditetapkan. } \\
\text { 14. Saya memiliki tanggungjawab atas pihak } \\
\text { eksternal yang mengevaluasi strategi Humas/. } \\
\text { 15. Saya bertanggungjawab dalam memantau } \\
\text { kinerja fungsi Humas sesuai dengan target yang } \\
\text { diharapkan. } \\
\text { 16. Melakukan negosiasi dengan divisi lain dalam } \\
\text { hal sumber daya dan beban kerja adalah salah } \\
\text { satu pekerjaan saya. } \\
\text { 17. Saya bernegosiasi dengan manajemen senior } \\
\text { untuk menetapkan target fungsi Humas. }\end{array}$ \\
\hline $\begin{array}{l}\text { Issues } \\
\text { management } \\
\text { expert }\end{array}$ & $\begin{array}{lr}\text { Berkaitan } & \text { dengan } \\
\text { peran Humas dalam } \\
\text { mendiagnosa dan } \\
\text { menanggapi ancaman } \\
\text { eksternal dari } \\
\text { masalah besar atau } \\
\text { kecil. }\end{array}$ & 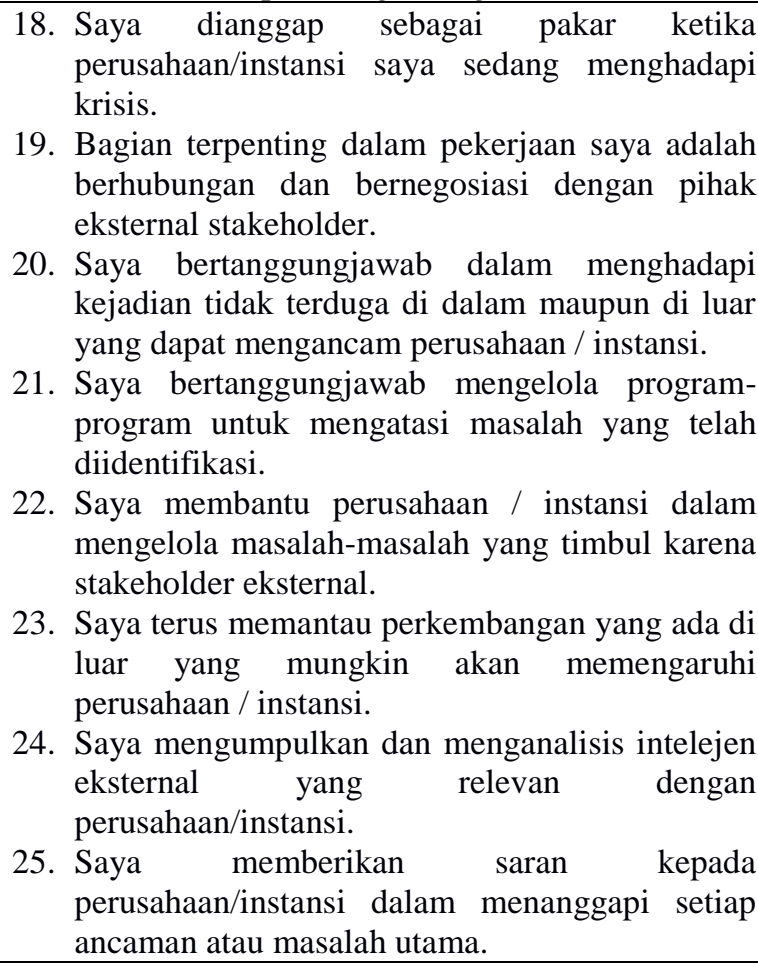 \\
\hline $\begin{array}{l}\text { Troubleshoot } \\
\text { ing/Problem- }\end{array}$ & $\begin{array}{l}\text { Berkaitan dengan } \\
\text { reaksi praktisi Humas }\end{array}$ & $\begin{array}{l}\text { 26. Saya sering menjadi "pemadam kebakaran" } \\
\text { dalam mengahadapi tantangan internal dan }\end{array}$ \\
\hline
\end{tabular}




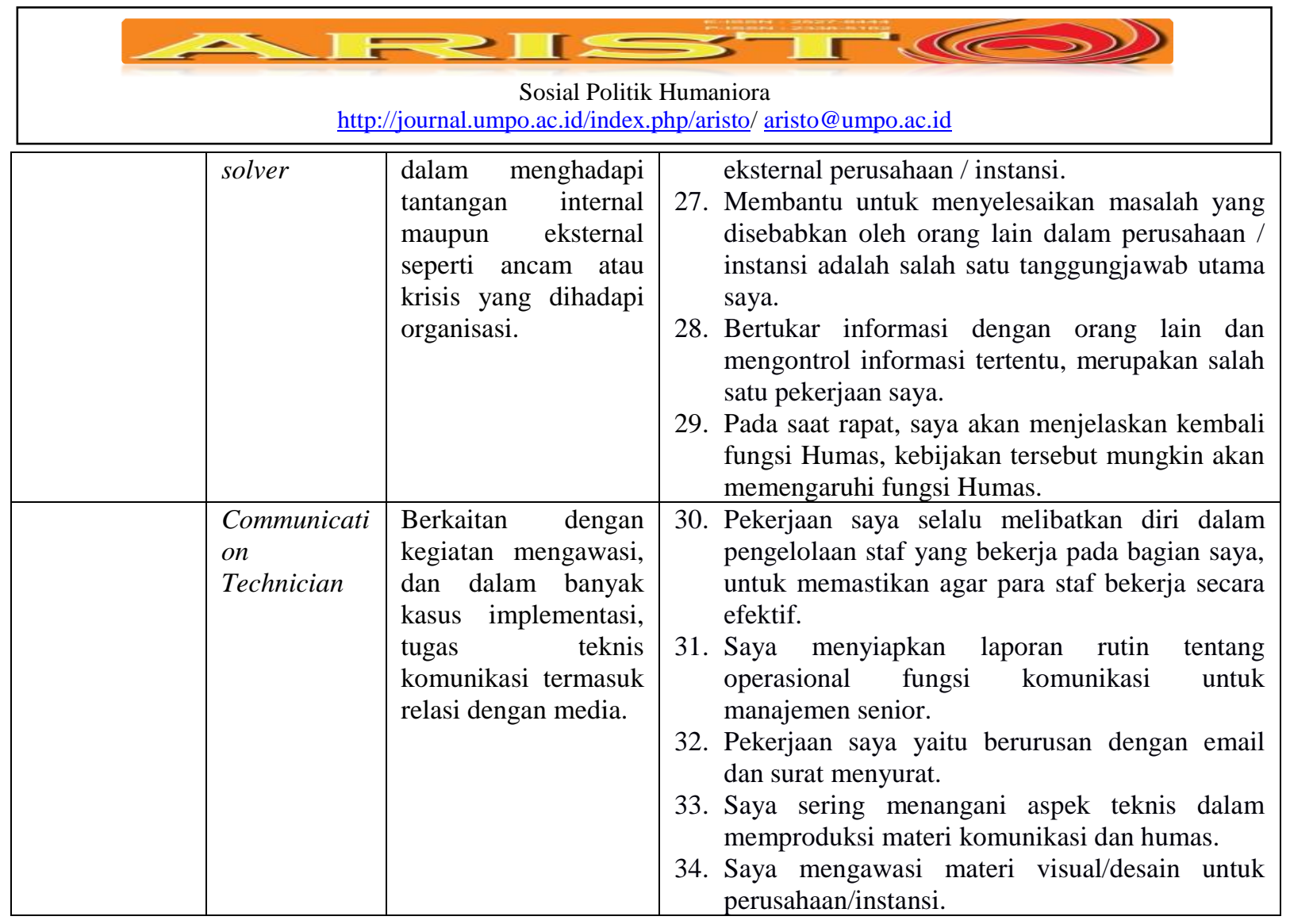

\section{HasildanPembahasan}

Dari penyebaran kuesioner, temuan penelitian ini tentang gambaran penerapan peran manajerial dan teknisi komunikasi pada praktisi Humas dan swasta disajikan di Tabel 2, sebagai berikut:

Tabel 2. Peran manajerial dan teknis Humas di Indonesia

\begin{tabular}{|l|c|c|}
\hline \multirow{2}{*}{ Dimensi } & \multicolumn{2}{|c|}{ Mean Score } \\
\cline { 2 - 3 } & Humas Swasta & Humas Pemerintah \\
\hline Key Policy dan Strategy Advisory & 3.27 & 3.81 \\
\hline Monitor dan Evaluator & 3.53 & 3.58 \\
\hline Issue Management Expert & 3.41 & 3.47 \\
\hline Troubleshooting/Problem Solving & 3.26 & 3.59 \\
\hline Communication Technician & 3.93 & 3.71 \\
\hline
\end{tabular}

Sumber: Kuesioner no 1-34

Tampak dari Tabel 2, berdasarkan pengakuan responden dapat ditemukan bahwa praktisi

Humas pemerintah memiliki nilai mean yang lebih besar dari semua aspek dimensi peran manajerial daripada Humas swasta. Hanya pada aspek kelima, yakni peran teknis, Humas swasta memiliki nilai mean lebih tinggi dari Humas pemerintah. Artinya, berdasarkan deskripsi setiap aspek, Humas pemerintah memiliki kecenderungan melakukan peran manajerial lebih sering 


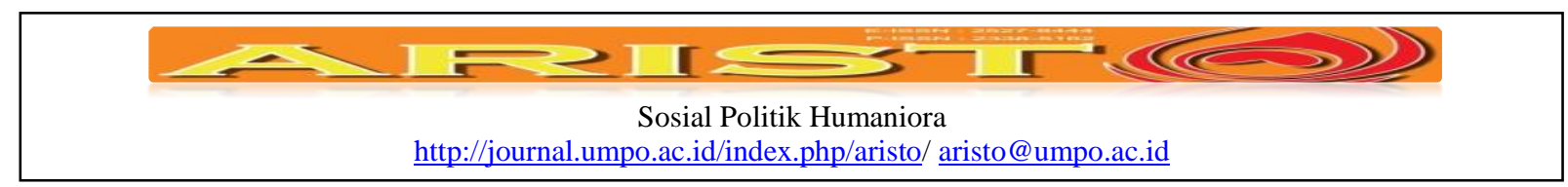

daripada Humas swasta sedangkan Humas swasta cenderung lebih sering melakukan peran teknisi komunikasi daripada Humas pemerintah. Untuk membuktikan pernyataan hipotesis penelitian maka penelitian ini mendeskripsikan temuan tentang perbandingan keseluruhan nilai mean peran manajerial dan teknisi pada kedua pihak praktisi Humas ini (Tabel 3).

Tabel 3. Perbandingan peran manajerial dan teknisi praktisi Humas

\begin{tabular}{|l|c|c|}
\hline \multirow{2}{*}{ Dimensi } & \multicolumn{2}{|c|}{ Mean Score } \\
\cline { 2 - 3 } & Humas Swasta & Humas Pemerintah \\
\hline Peran Manajerial & 3.37 & 3.62 \\
\hline Peran Teknisi & 3.93 & 3.71 \\
\hline
\end{tabular}

Sumber: Kuesioner no 1-34.

Berdasarkan deskripsi di Tabel 3, penelitian ini menemukan fakta bahwa kedua praktisi, yakni Humas pemerintah dan swasta ternyata sama-sama cenderung lebih sering menerapkan peran teknisi komunikasi dalam aktivitas mereka menjalankan fungsi kehumasan. Tetapi, selisih nilai mean antara peran manajerial dan teknisi pada Humas pemerintah lebih sedikit, yakni 0.09 sedangkan Humas swasta memiliki selisih nilai mean lebih besar, yakni 0.56. Hal ini memperkuat temuan di Tabel 2 bahwa meski melakukan peran teknisi, tetapi, Humas pemerintah memiliki peluang kecenderungan melakukan peran manajerial lebih besar daripada Humas swasta. Jika Tabel 3 ini dikaitkan dengan Tabel 2, ditemukan fakta bahwa Humas pemerintah lebih sering melakukan peran manajerial daripada Humas swasta dan Humas swasta lebih sering melakukan peran teknisi dibanding Humas pemerintah.

Pada akhirnya, peneliti dapat menyimpulkan bahwa hipotesis penelitian ini tidak diterima atau tidak dapat dibuktikan kebenarannya. Jadi, dapat disimpulkan bahwa Humas pemerintah dan swasta sama-sama lebih sering menjalankan peran teknisi komunikasi daripada peran manajerial komunikasi, meskipun kecenderungan melakukan peran manajerial lebih ditemukan pada Humas pemerintah.

Penelitian ini menghasilkan temuan yang menarik. Pertama, penelitian ini memperkuat hasil penelitian Perthawa dkk (2015) yang menemukan bahwa Humas pemerintah dan swasta sama-sama cenderung lebih sering melakukan peran teknisi komunikasi daripada peran manajerial. Meskipun demikian, pada kedua penelitian ini pun ditemukan bahwa Humas pemerintah cenderung melakukan peran manajerial lebih sering daripada Humas swasta, yakni 


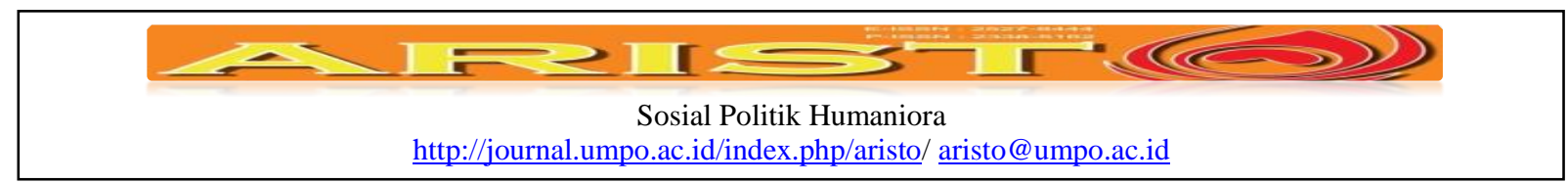

selisih nilai tengah peran manajerial dan teknis pada Humas pemerintah hanya 0.9 sedangkan pada Humas swasta 1.52 .

Kedua, jika dibandingkan penelitian Grunig dkk (2002) dan Kriyantono (2017), penelitian ini menghasilkan temuan berbeda. Penelitian Grunig dkk (2002) dan Kriyantono (2017) menghasilkan temuan bahwa Humas swasta secara umum lebih ekselen dengan menggunakan instrument pengukuran dalam kuesioner yang lebih luas, yakni bukan hanya dimensi peran manajerian dan teknis saja. Kedua penelitian pendahuluan ini juga mengevaluasi dimensi etika, pengetahuan, arah komunikasi satu arah atau dua arah, struktur lembaga kehumasan, dan pemberdayaan praktisi Humas. Jadi, hasil penelitian yang sedang berlangsung ini hanya terbatas berlaku hanya dari satu aspek dimensi, yakni dimensi peran.

Namun demikian, lebih seringnya Humas pemerintah dalam melakukan peran manajerial merupakan temuan yang menarik jika dikaitkan dalam konteks perkembangan demokrasi dan perubahan paradigm pemerintahan kita. Peneliti berpendapat bahwa hasi temuan ini disebabkan proses demokrasi di Indonesia saat ini yang menstimuli aktivitas komunikasi dengan publik yang makin memerlukan praktisi Hubungan Masyarakat (Humas/Public relations) untuk mengelola dengan lebih baik (Kriyantono, 2014a; Kriyantono, dkk, 2015; Sriramesh \& Vercic, 2009).

Aktivitas komunikasi ini merupakan implikasi dari sifat demokrasi, yang menurut Taylor (2000), sebagai proses nation-building yang mensyaratkan jalinan relasi antara individu dan pemerintah, melalui kampanye komunikasi. Karena itu, bukan situasi yang mengherankan jika pertumbuhan praktik Humas di dunia semakin meningkat seiring berkembangnya demokratisasi dan teknologi (Sriramesh \& Vercic, 2009). Hal ini diperkuat Hopkins (2015, h. 3), mengutip Gelders \& Ihlen (2010, h. 61): “Government public relations can also be considered a part of the democratic process."

Sebagai proses nation-building, dapat dikatakan bahwa demokratisasi berdampak luas bagi aktivitas lembaga, khususnya lembaga pemerintah yakni lembaga yang menurut UU no 25/2009 menyelenggarakan pemerintahan dan pelayanan publik (Kriyantono, 2015). Demokrasi mendorong munculnya active public, yaitu publik yang secara aktif mencari informasi, bukan pasif hanya menerima informasi (Grunig \& Hunt, 1984; Lee \& Rodriguez, 2008; Magdalena, Kriyantono \& Pratama, 2015). Sebagai akibatnya, prinsip keterbukaan informasi merupakan keniscayaan yang mesti dilakukan untuk mewujudkan terlaksananya good-governance dalam pelayanan informasi publik, seperti diatur dalam UU no 14/2008 tentang Keterbukaan Informasi 


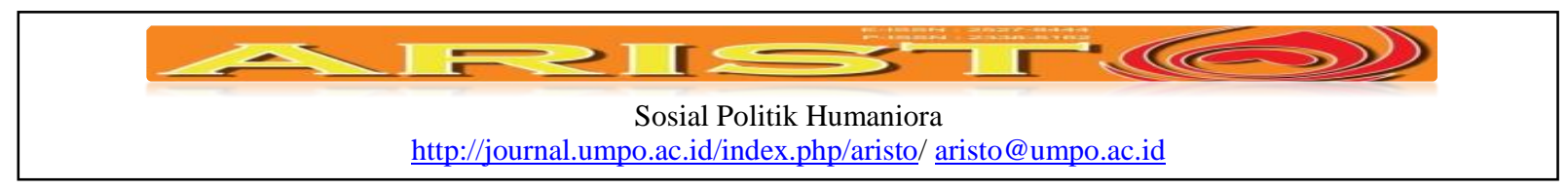

Publik (KIP). UU ini merupakan implementasi dari pasal 28F UUD 1945 yang menjamin hak publik memperoleh informasi.

Informasi publik, menurut UU KIP, adalah muatan informasi yang dikelola, dikirim dan diterima oleh suatu badan publik terkait dengan penyelenggara dan penyelenggaraan negara dan badan publik. UU KIP menyatakan bahwa informasi publik harus bersifat terbuka, dapat diakses dengan cepat, tepat waktu, tidak berbeli-belit, terjaga keakuratannya dan kebenarannya, serta tidak menyesatkan. Informasi tersebut dapat digunakan publik untuk menginterpretasi peristiwaperistiwa kehidupan yang berkaitan dengan kepentingan umum (pasal 6 bagian d UU 40/1999), termasuk informasi-informasi publik tentang pembangunan, pemerintahan, dan pelayanan publik.

Pelayanan publik, menurut UU no 25/2009, merupakan tugas pokok lembaga penyelenggara negara. Berdasarkan UU KIP, lembaga pemerintah sebagai lembaga pelayanan publik harus dapat menjamin hak warga negara untuk mengetahui rencana pembuatan kebijakan publik, program kebijakan publik, dan proses pengambilan keputusan publik serta alasan pengambilan suatu keputusan publik. Mengacu pada UU no 25/2009, tampak bahwa asas-asas pedoman pelayanan, seperti profesionalitas penyelenggara, partisipatif, keterbukaan, dan akuntabilitas proses pelayanan, sangat bergantung pada fungsi pengelolaan komunikasi yang diterapkan. Jadi, dari analisis literatur dan temuan data, dapat disimpulkan bahwa perkembangan demokrasi dan perubahan paradigm pemerintahan di Indonesia saat ini secara langsung membuat perubahan paradigm kehumasan pemerintah.Besarnya peran teknis yang masih dilakukan Humas pemerintah tampaknya terkait dengan bidang pekerjaan peran ini. Peran ini lebih banyak mengurus hal-hal komunikasi yang bersifat teknis, seperti menulis press-release, membuat majalah atau protokoler, juga termasuk pengelolaan staf yang bekerja pada bagian saya, untuk memastikan agar para staf bekerja secara efektif, menyiapkan laporan rutin tentang operasional fungsi komunikasi untuk manajemen senior, berurusan dengan email dan surat menyurat, menangani aspek teknis dalam memproduksi materi komunikasi dan Humas, dan mengawasi materi visual atau desain untuk organisasi (De Santo, dkk, 2007; Kriyantono, 2014a; Moss \& De Santo, 2011; Perthawa, dkk, 2015, dan Whitaker, 2014. Peneliti berpendapat bahwa jenis pekerjaan tersebut tidak terlalu menuntut kemampuan manajerial dan analisis lebih mendalam. 


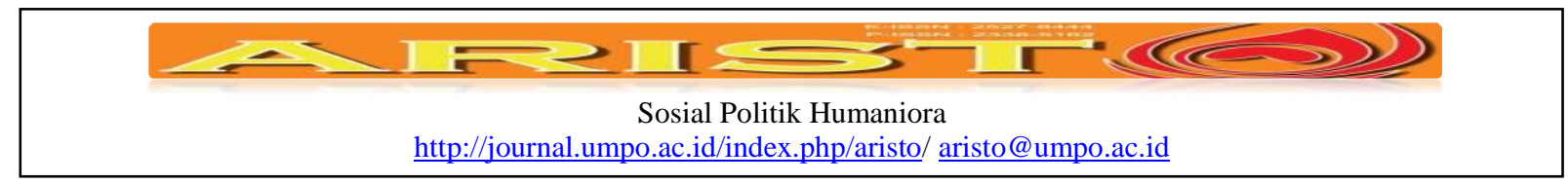

\section{Kesimpulan}

Dari temuan data dalam penelitian ini, dapat disimpulkan bahwa tidak ada perbedaan yang signifikan antara praktik humas pemerintah dan swasta terkait dengan dimensi peran manajerial dan teknisi komunikasi. Kedua jenis Humas sama-sama lebih sering menerapkan peran teknisi komunikasi daripada peran manajerial komunikasi, namun Humas pemerintah lebih sering melakukan peran manajerial daripada Humas swasta. Penelitian ini juga mengonfirmasi bahwa praktik Humas pemerintah sudah berkembang sesuai tuntutan demokratisasi dan paradigm pemerintahan yang good governance dalam pelayanan publik.

Untuk penelitian di masa datang, peneliti merekomendasikan untuk memperdalam penelitian ini dengan melakukan penelitian konstruktivis dengan cara melakukan wawancara mendalam kepada praktisi. Wawancara mendalam ini bertujuan menggali data tentang motif, sikap-sikap atau nilai-nilai yang lebih mendalam sehingga benar-benar dapat memverifikasi temuan data penelitian ini. Penelitian ini memang mengandung limitasi karena hanya menggali data di permukaan karena keterbatasan paradigm positivistik. Selain itu, penelitian ini belum dapat digeneralisasikan secara lebih luas untuk dapat disebut mewakili gambaran praktik Humas di seluruh Indonesia karena keterbatasan responden. Di masa datang, direkomendasikan melakukan survey nasional dengan responden yang mewakili praktisi Humas seluruh Indonesia. 


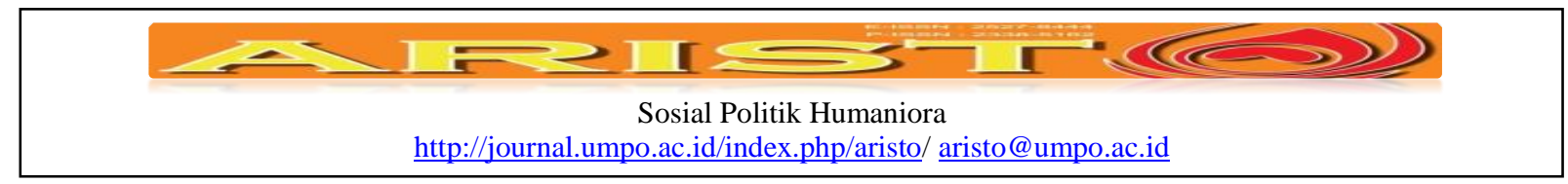

\section{Daftar Pustaka}

Broom, G., \& Sha, B. (2013). Cutlip and center's effective public relations (11th ed.). UppervSaddle River, NJ: Prentice Hall.

Culbertson, H. M., Jeffers, D. W., Stone, D. B., \& Terrell, M. (1993). Social, political, and economic contexts in public relations: Theory and cases. New York: Lawrence Erlbaum Associates Publisher.

Cutlip, S. M., Center, A. H., \& Broom, G. M. (2011). Effective public relations (B. S. Tri Wibowo, Trans.). Jakarta: Kencana Prenada Media.

De Santo, B., Moss, D., \& Newman, A. (2007). Building an understanding of the main elements of management in the communication/public relations context: A study of U.S. practitioner practices. Association for Education in Journalism and MassCommunications, 84(3), 439-454. doi: 10.1177/107769900708400303.

Grunig, L.A., Grunig, J.E., \& Dozier, D.M. (2002). Excellence in public relations and communication management: A review of the theory and results. Dalam Grunig, L.A., Grunig, J.E., \& Dozier, D.M. (Eds.). Excellent public relations and effective organization. New Jersey: Lawrence Erlbaum.

Grunig, J.E., \& Hunt, T. (1984). Managing public relations. New York: Holt, Rinehart \& Winston, Inc.

Hardjana, A. (2000). Audit komunikasi. Jakarta: Gramedia.

Harrison, K. (2009). Strategic public relations: A practical guide to success (5 ed.). Perth: Century Consulting Group.

Hendrix, J. A. (2000). Public relations cases. California: Wadsworth.

Hopkins, A. E. (2015). Government public relations: Public diplomacy or propaganda? Student Pulse [Online], 7 (3). Available on http://www.studentpulse.com/a?id=1012

Ikhsan, M. (2015). Pemerintahan di Sumatera Selatan masihtertutupdenganinformasipengelolaankehutanan: Adakah yang dirahasiakan? http://www.mongabay.co.id. Retrieved February 27, 2015.

Kriyantono, R. (2017). Do the different terms affect the roles? A measurement of excellentand managerial role of business and government public relations practices in Indonesia. International Journal of Applied Business \& Economic Research, 15(6), 193-209.

Kriyantono, R., \& McKenna, B. (2017). Developing a culturally-relevant public relations theory for Indonesia. Malaysian Journal of Communication, 33(1), 1-16. 


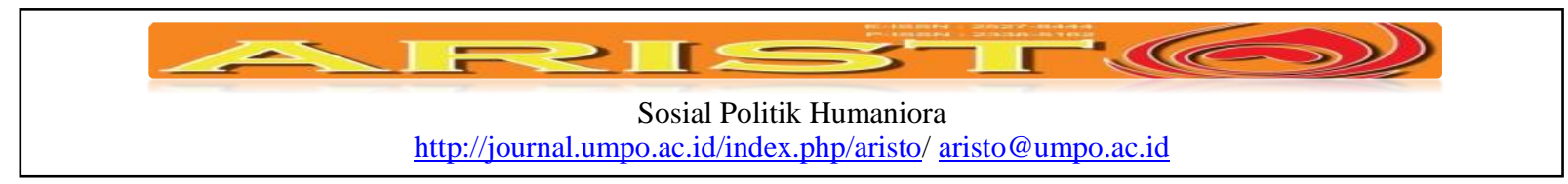

Kriyantono, R., Ramadlan, M. F., Setiawan, A. (2015). Hidden advertising in local election era: Reducing the public's right of information and critical power of media in Indonesia, International Journal of Development Research, 5(10), 5875-5880.

Kriyantono, R. (2015). Konstruksi public relations dalam tata kelola komunikasi lembaga pendidikan tinggi dalam era keterbukaan informasi publik. Jurnal Pekommas, Kominfo Makassar, 18(2), 117-126.

Kriyantono, R. (2014a). Teori public relations perspektif barat dan lokal: Aplikasi penelitian dan praktis. Jakarta: Prenada Media.

Kriyantono, R. (2014b). Teknik praktis riset komunikasi (Cet ke-7). Jakarta: Kencana Prenada Media.

Kriyantono, R. (2014c). Public relations writing (Cet ke-4). Jakarta: Kencana Prenada Media.

Lattimore, D., Baskin, O., Heiman, S., \& Toth, E. (2010). Public relations: The profession and the practice. New York: McGraw-Hill.

Lee, S., \& Rodriguez, L. (2008). Four publics of anti-bioterrorism information campaigns: A test of the situational theory. Public relations Review, 34, 60-62.

Magdalena A., Kriyantono, R., \& Pratama, B.I. (2015). Identifikasi publik berdasarkan persepsi situasional pada isu seputar pemilihan umum presiden tahun 2014 pada publik kota Malang, Jurnal Penelitian Komunikasi, Informatika, dan Media Massa, 18(1), 37-44.

Marston, J. E. (1979). Modern public relations. New York: McGraw-Hill.

Moss, D., \& De Santo, B. (2011). Public relations: A managerial perspective. California: Sage.

Moss, D., Newman, A. \& De Santo, B. (2005). What do communication managers do? defining and refining the core elements of management in a public relations/corporate communication context. Journalism \& Mass Communication Quarterly 84 (winter 2005): 873-90.

Neuman, W. L. (2006). Social research methods: qualitative and quantitative approaches - 6th Edition. Boston: Pearson Education.

Parthawa, P.B., Kriyantono, R., \& Wisadirana, D. (2015). A test of five-factor model on different roles of government and private public relations practitioners in Indonesia. Global Journal of Human Social Science Volume XV Issue IV Version I, 17-22.

Siriyuvasak, U. (2005). People's media and communication rights in Indonesia and the Philippines, Inter-Asia Cultural Studies, 6(2), 245-265.

Rachmat Kriyantono, Peran Manajerial dan Teknisi Humas Lembaga Pemerintah dan Swasta/01/ Vol. 6. No.1. Tahun 2018 


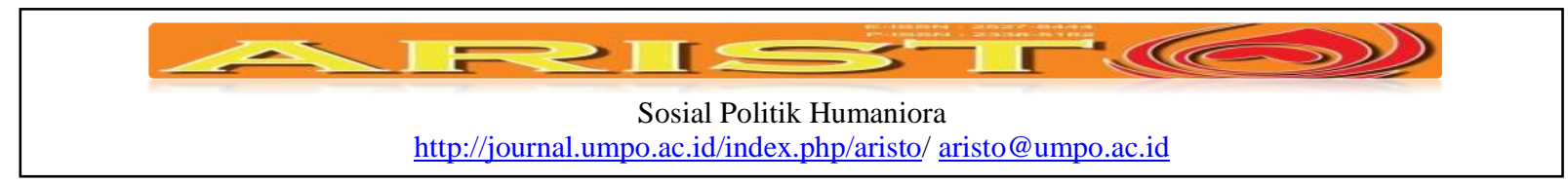

Smith, R. D. (2002). Strategic planning for public relations. New Jersey: Lawrence Erlbaum Associates.

Sriramesh, K., \& Vercic, D. (2009). A theroritical framework for global Public relations research and practice. In K. Sriramesh \& D. Vercic (Eds.), The global Public relations handbook: theory research, and practice (pp. 3-24). New York, NY: Taylor and Francis Group.

Taylor, M. (2000). Toward a public relations approach to nation-building.Journal of Public Relations, 12(2), pp. 179-210.

Tymson, C., Lazar, P., \& Lazar, R. (2004). The new Australian and New Zealand Public relations manual. NSW: Tymson Communication.

Whitaker-Heck, R, E. A. (2014). An examination of the roles and work activities of the public relations officer in higher education using the five-factor dimension model.Public Relation Society of America,8(1), 9-14.

Wilcox, D.L. \& Cameron, G.T. (2009). Public relations: strategies \& tactics ed. $9^{\text {th }}$. Boston: United States of America.

Wilcox, Ault, \& Agee. (2006). Public relations strategidantaktik.Batam: Interaksara.

Wimmer, R.D.,\& Dominick, J.R. (2011). Mass media research: an introduction, ninth edition. Boston: Wadsworth. 